\section{MUSLIM COMMUNITIES DURING THE AYUTTHAYA PERIOD}

\author{
Julispong Chularatana ${ }^{1}$
}

\begin{abstract}
The Muslims in Ayutthaya were divided into distinct groups. The first, the IndoMalay Muslims, and the second, the Sunni Muslims from the countries to the west of Siam, were the groups outside the city wall, while the third resided inside the city wall. This third group consisted mainly of Indo-Iranian Muslims of the Shiite sect, different from the first and the second groups, who were primarily of Sunni sect of the Shaf'is group. The differences in their religion, race, society, and culture caused these Muslims to separate into different communities in the city of Ayutthaya.
\end{abstract}

\section{Introduction}

Thai people have long had experience of living with foreigners of different nationalities, religions, societies, and cultures, with generally good relations all around. History tells many tales reflecting the reasons and factors that brought peace. If the professionals in various fields would pay attention to the study of Muslim history, it would create better understanding of the Islamic world than is often found at present. Then, finally, the different viewpoints would not be a source of disharmony but would instead lead to the search for a way to live together in

${ }^{1}$ Lecturer, Department of History, Faculty of Arts, Chulalongkorn University, Thailand peace, which is the real objective of all religions in the world. Articles on the Muslim communities during the Ayutthaya period reflect the differences of the various groups of Muslim who have been in Thai society for a long time, especially the Muslims in the central region whose historical context was not the same as Muslims in other parts of the country. Studying them widens and deepens dimensions and opinions which can be the basis for policies formation in the future.

\section{From Islamic World to the Land of Siam}

The Islamic religion originated in Arabia in the seventh century and later spread to the surrounding regions. Muslim communities expanded and settled in North Africa, Iran (Persia), Central Asia, Southern Europe, India, and the lower part of Southeast Asia. The Islamic religion was very powerful in Southeast Asia beginning in the tenth century (Sardesi, 1994: 54) and spread all over the Malay Peninsula, Archipelago, and Entrepôts. The spread of the religion was supported by Muslim rulers, as Islamic Religious Mandates stated that the heads of state were responsible for spreading the religion to the people of other nations. Furthermore, the decrees of the Quran and Hadis encouraged traveling to spread the holy religion to other lands as a holy pilgrimage (Roberts, 1971: 99). Hence, the Islamic religion arrived with Muslim trading caravans journeying from the west to the east of Asia by the Silk Roads over land and sea.

During the eleventh century, Muslim merchants from Arabia, Egypt, Turkey, and Iran formed commercial groups and sent out caravans to trade in various cities, 
both by land and sea (Chaudhuri, 1990: 34; Dunn, 1989: 248-249). Muslim commerce had operating plans and investments and included setting up of trading caravans for both by land and sea. From the eleventh to the fifteenth centuries, Muslim fleets were considered modern and had established a network of shipping routes from Africa to China (Ezzati, 1944: 314; Chaudhuri, 1990: 44; Lieberman, 1993: 542; Moreland, 1939: 63-74). Muslim merchants from Arabia, Egypt, Africa, Iran, Central Asia, India and China linked trade from the Mediterranean Sea with the eastern Indian Ocean and the South China Seas, the Red Sea and the Arabian Seas. At the same time, the Muslims were also trading on land along the Silk Roads and developed entrepôts to connect land trade to sea trading. ${ }^{2}$

The Muslim fleet had shipboard organization as well as training in navigational skills (Reid, 1988: 27-28). The chief of the trading fleet held the position of nakhoda, which means 'ship master' in Arabic (Chaudhuri, 1990: 61). The nakhoda was the head of trade for various states in Southeast Asia (Reid, 1999: 132-133). The rulers of the different states in South Asia and Southeast Asia that traded by sea during the fifteenth and sixteenth centuries all appointed Muslim ship masters and traders (Risso, 1995: 49).

Muslims who traded in foreign lands formed their own communities called umma. These were associations based on society, religion, and culture which at the same time helped to build economic

\footnotetext{
2 The Silk Road trades, which was developed by the Muslims, were connected from China to the Persian Gulf and the Mediterranean See also K. N. Chaudhuri (1992: 88-89).
}

power. ${ }^{3}$ Umma also served as the network for social, religious, and trading connections among Muslim merchants in adjoining regions (Gupta, 1994: 12). Leaders were selected within each community to control and look after the people and trading stations. Community leaders played a role in the commerce and governance of the community. The unity among the Muslim merchants created cooperation in operating investment and merchant fleets, putting the Muslim merchants in a vital role in the trade around the Indian Ocean from the eleventh century on (Chaudhuri, 1990: 11-12).

Over and above the cooperation in setting up communities that benefited merchant fleets, the Muslims also formed groups to handle trading activities under a system called commenda, a Medieval Latin word meaning an agreement or contract to invest together (Matthee, 1999: 88). It was a system set up by Arabian merchants to collect operating investments and to be mutually responsible for the profit accrued and debt incurred in trade (Risso, 1995: 19). Such cooperation also extended to allies who were not Muslim merchants, ${ }^{4}$ resulting in a wide network of merchants among the Muslims and non-Muslims.

\footnotetext{
${ }^{3}$ In the Quran, umma usually refers to communities sharing a common religion, whereas in later history it almost always means the Muslim community as a whole. The umma's establishment is a community with political authority and autonomy, as well as religious social and economic characteristics. See also F. M. Denny 'Umma,' in The Encyclopaedia of Islam Online, http:// www.encislam.brill.nl/start2.asp.

${ }^{4}$ Shah Abbas I, the Safavid, promoted the commenda system by supporting trade agreements among Iranian, Armenian and Western merchants. See also Matthee (1999: 88).
} 
The chief of a trading community would hold the title of shahbandar, ${ }^{5}$ whose duty was to control the ships entering and leaving entrepôts, trading among the countries. He also took charge of the depots and was the commander in charge of defending the entrepôts and depots against enemy attacks from the sea. Moreover, the shahbandar controlled all foreigners in the entrepôts and was also Chief of Customs (Risso, 1995: 120). Therefore, the position of shahbandar had the duties of controlling commerce, foreign affairs, and the Muslim communities.

The Muslims developed their trade, commerce, and finance to the point of creating an Islamic economic principle ${ }^{6}$ which caused the birth of a trading culture in the Muslim world. This trading culture included the use of a common language (Arabo-Iranian) a currency system, and a standard of currency exchange. Also included were commercial formats such as accounting and depot management. ${ }^{7}$ All

\footnotetext{
5 Shahbandar means 'king of the haven' or 'harbor master.' After the Muslim merchants were able to control the main sea trade route in the Red Sea during the twelfth and fifteenth centuries, many foreign Muslims from western Asia were appointed as shahbandars of the seaports of India and the archipelagos of Southeast Asia. See also Catz (1989: 56), Noorduyn (1956: 238); as cited by Winstedt, 1961: 76), Meillink-Roelofsz (1962: 7), and Moreland (1920: 517).

${ }^{6}$ Islamic Economy was based on the Shari'a (the Rule of Allah); thus it not only took cognizance of economic factors but also complied with the elements of sociopolitical and Islamic moral and laws. See also Mannan (1996: 4-5) and Ezzati (1944:311).

7 The process of early Muslim commerce was developed in Jahiz's Mercantile Handbook,
}

these formats played an integral part in promoting the role of Muslims in the trade network of the Indian Ocean.

The Muslims had formed a trading group in the west of Siam in the early Ayutthaya period or even before then. From Tomé Peres, a Portuguese who traveled through Siam around the sixteenth century, one learns of Siam's relationships with the different groups of Muslims. 'On the Tanasserim side Siam also trades with Pase, Pedir, with Kedah, with Pegu, with Bengal; and the Gujaratees come to its port every year. They trade richly outside and liberally inside, but they are great tyrants' (Cortesoa, 1990: 109). Most of the merchants from those places were Muslims. Duarte Barbosa, a Portuguese traveler based in Cambay, in the state of Gujarat in India, between 1500 and 1516 A.D., said that there were many merchants both Moor and Heathen in a sea-haven which was called Tanaçary (or Tanasserim). They also passed many ships sailing to Bengal, Malacca, and Kedah (Barbosa, 1967: 164-165). This shows the important role the Muslims played in Siam and the surrounding regions during early Ayutthaya period, and they were probably settling in Siam from that time on.

The settlement of the Muslims in Siam was the effect of three factors: religion, economy, and politics. First, the push to spread the Islamic religion in the thirteenth to the fifteenth centuries resulted in many religious leaders moving in to settle and spread the Islamic religion in Siam. Secondly, the expansion of trade by Muslims into South Asia, Southeast Asia,

which was written in the middle of the ninth century. It had an influence on the development of Muslim trade and commerce. See also Udovitch (1970: 37-39). 
and East Asia, coupled with the desire of the Siamese Royal Court to expand trade to bring more income to the Royal Treasury, played a part in encouraging more Muslim trade and settlement in Siam. Thirdly, as a result of changes in the politics of Muslim states in the Middle East, India, and Southeast Asia, Muslim communities migrated to request political asylum in Siam. At that time, Siam maintained an open religious policy for the Muslim population. Therefore, these three factors encouraged more Muslims to migrate into Siam, resulting in large foreign communities in important towns throughout the kingdom. ${ }^{8}$ Starting in the sixteenth century, the Muslims played an important part in the economy, society, religion, culture, and politics of the court of Siam.

\section{Muslim Communities during the Ayutthaya Period}

The Siamese referred to the various Muslim groups as a whole by the term 'Khaek'. This term was used to label people from countries to the west of Thailand who were Indian, Iranian, Arabian, or Middle Eastern and who were mainly of the Islamic religion. Other nationalities from the west who were not Muslims but were likewise not Europeans also fell under the category of 'Khaek', for example, the Hindu 'Khaek'. Later on, the Malays were also called 'Khaek'. From documents and evidence in Thai history, the 'Khaek' immigrants into Siam may be separated into two groups. The first group consisted of those professing the Islamic faith, e.g., Khaek Malay, Khaek Cham,

\footnotetext{
${ }^{8}$ They were situated near the capital city and were closely controlled by the central Siamese administration.
}

Khaek Yawa (Khaek Java), Khaek Makassar and Khaek Chao Sen (Khaek Mankhon, or Shiite Muslims). The other groups were those of other religions, e.g., Khaek Brahman, Khaek Hindu and Khaek Sikh. The Siamese used the term 'Khaek' first in the sense of 'foreigners,' and later to designate the people from the west who were not Europeans (The Thai Encyclopedia of the Royal Academy 4, 1969: 2273-2272). To differentiate among the 'Khaek', the regions, nationalities, or religions were used together to signify the type of 'Khaek', e.g. Khaek Cham, Khaek Yawa, Khaek Khorasan, ${ }^{9}$ and Khaek Chao Sen.

Tomé Peres mentioned the settlement of Muslims of many nationalities along the Siamese entrepôts, including Arabs, Persians, Bengalis, Chinese, and other nationalities including the Moors (Cortesoa, 1990: 104), which meant Indians from the Kling State. Fernão Mendes Pinto, a Portuguese traveler who passed through Siam in the mid-sixteenth century during the reign of King Chai Rajathirach (Somdej Phra Chai Rajathirach), wrote of two Turkish marshals who lived in Ayutthaya and led the foreign troops to join the Siamese armies to attack the kingdom of Chiang Mai in 1547-1548. He also stated that there were seven mosques of the Turks and the Arabs and about 30,000 residences of the Moors in the capital of Siam (Pinto, 1904: 63-65).

\footnotetext{
${ }^{9}$ Khorazan, or Khurazan, is a region on the northeastern part of Iran, thus Khaek Mueng Khorasan refers to a Muslim from that province (the Khurazani). There were many Khurazanis in Siam and they played their roles in King Narai's reign. See also Chularatana (1999: 107) and Rabi (1972: 99).
} 
The communities of the Muslims in Ayutthaya were separated into groups in accordance with nationalities, original regions, and professions. On the map in the description of Simon de la Loubère, the second envoy of King Louis XIV to King Narai's court in 1687, two locations of Muslims were marked - the Makassars ${ }^{10}$ and the Malays, who resided along the river banks outside of the city wall to the south west. The town plan of Ayutthaya by French engineers during the reign of King Narai (Somdej Phra Narai) showed communities of the Chinese and the Moors located inside the city wall on the south west. The same was true on the map of Engelbert Kaempfer, the German physician who came to Siam in 1690 in the reign of King Phet Raja (Somdej Phra Phet Raja) (Kaempfer, 1987: 43, 77). Kaempfer's description also said that the central city road linking the north of the city to the palace consisted of shops of the Chinese, the Hindustani, and the Moors (1987: 44).

The Thai documents describing the various Muslim groups during the Ayutthaya period are Khamhaikarn Chao Krung Kao, which compiles the testimonies of those people captured by the Burmese in 1767, and Khamhaikarn Khunluang Wat Pradu Songtham or Khunluang Ha Wat, supposedly written by the residents of Ayutthaya in the early Rattanakosin period. Those documents explained that the Muslim communities were situated on the Thanon Ban Khaek Yai 'Grand Muslim Street' in the center of Ayutthaya city (Pongsripean, 1985: 7). It was called Rue des Moores or Moor Street in European documents.

\footnotetext{
${ }^{10}$ Makkasan, or the Makassarese, are the Muslims from Sulawesi Island in Indonesia.
}

Khamhaikarn Khunluang Wat Pradu Songtham gave details of the settlements of the various Muslim groups in the Ayutthaya period, namely that Khaek Cham and Khaek Thet resided on floating houses on the two sides of the river from the end of Wat Suwan Dararam canal up to the front of the Wang Lang (the Palace of the Third King). In the area of Tha Kayi 'Kayi Port' outside of the city wall were the residences of the Khaek who had the profession of making cabin ropes from coconut husks. They also had shops selling household items spread around various communities. Khaek Cham parked their boats and rafts to sell their rattan wares at Ban Nam Won Bang Kracha. Those residing in the area of Ban Tai Ku had the profession of weaving reed mats for sale. Khaek Yawa and Khaek Malay loaded their large boats with beetlenuts and rattan baskets and anchored at the mouth of $\mathrm{Ku}$ Cham canal. Khaek Tani wove silk and cotton materials at Ban Rim Wat Lodchong. Other Khaek (no nationalities mentioned) had shops selling wrist and ankle bracelets, hair pins, rings, beads, and decorative accessories at the bottom of the Chi Khun Bridge Westside (Pongsripean, 1985: 6-7, 15).

The evidence above showed that there were three large areas or communities of Muslims in Ayutthaya. The first consisted of the communities on the banks of the Chao Phraya River opposite the south and southwest city wall, the second group was the communities inside the outer city wall near canals or the river, and the third group comprised the communities inside the city wall. However, other Muslims were spread around other areas, mainly near the river or canals or the trading areas or markets that were in contact with the city communities. 
Muslims of the Cham and Malay groups and from the Southeast Asian Archipelago who resided in communities along the banks of the Chao Phraya River opposite the south and southwest city wall were the Muslims of Malay race or Muslims from the states of the Malay Archipelago, the Muslims from the Makassar State from the Southeast Asian Archipelago, and the Muslim Cham. These Muslims consisted of both traders and political refugees that were swept into the country, so they were of varied professions and classes, even some who came with their masters, such as the Makassars (Rabi, 1972: 137; Cady, 1964: 219).

The Muslims from the Malay peninsula who settled in Siam ranged from merchants to slaves (Pongsripean, 1985: 7). ${ }^{11}$ Moreover, there were also prisoners of war from occasional fights between the Muslim states in the Malay peninsula and Siam. ${ }^{12}$ Most Malay merchants lived in communities along the waterways with easy access for trading. Others resided outside of the city wall in the south, adjacent to the Cham communities. The

\footnotetext{
${ }^{11}$ According to the Suma Oriental of Tomé Peres, some merchants from Pattani, Kedah, Kalantan, and Trangkanu had traded with the Chinese and Moors at the seaports of Siam. Some kind of the goods from Malaka, which were traded in Siam, included men and women Malay slaves. They might be provided for. The Chevalier de Chaumont related that most of the Malays in Siam were slaves and laborers. See also Smithies (1997: 84).

${ }^{12}$ Some Muslim kingdoms in the Malay Peninsula such as Pattani and Kedah, had been tributary states of Siam. When they tried to overthrow the control of the Siamese administration, the Siamese king would send their troops to subdue and forcibly move some Malay people to Ayutthaya. See also Teeuw and Wyatt (1970: 228-235).
}

Muslims from the Southeast Asian archipelago states, namely Java and Makassar, were merchants and political refugees due to the invasions by the Dutch (Hall, 1994: 346-347) or from power struggles among themselves. 


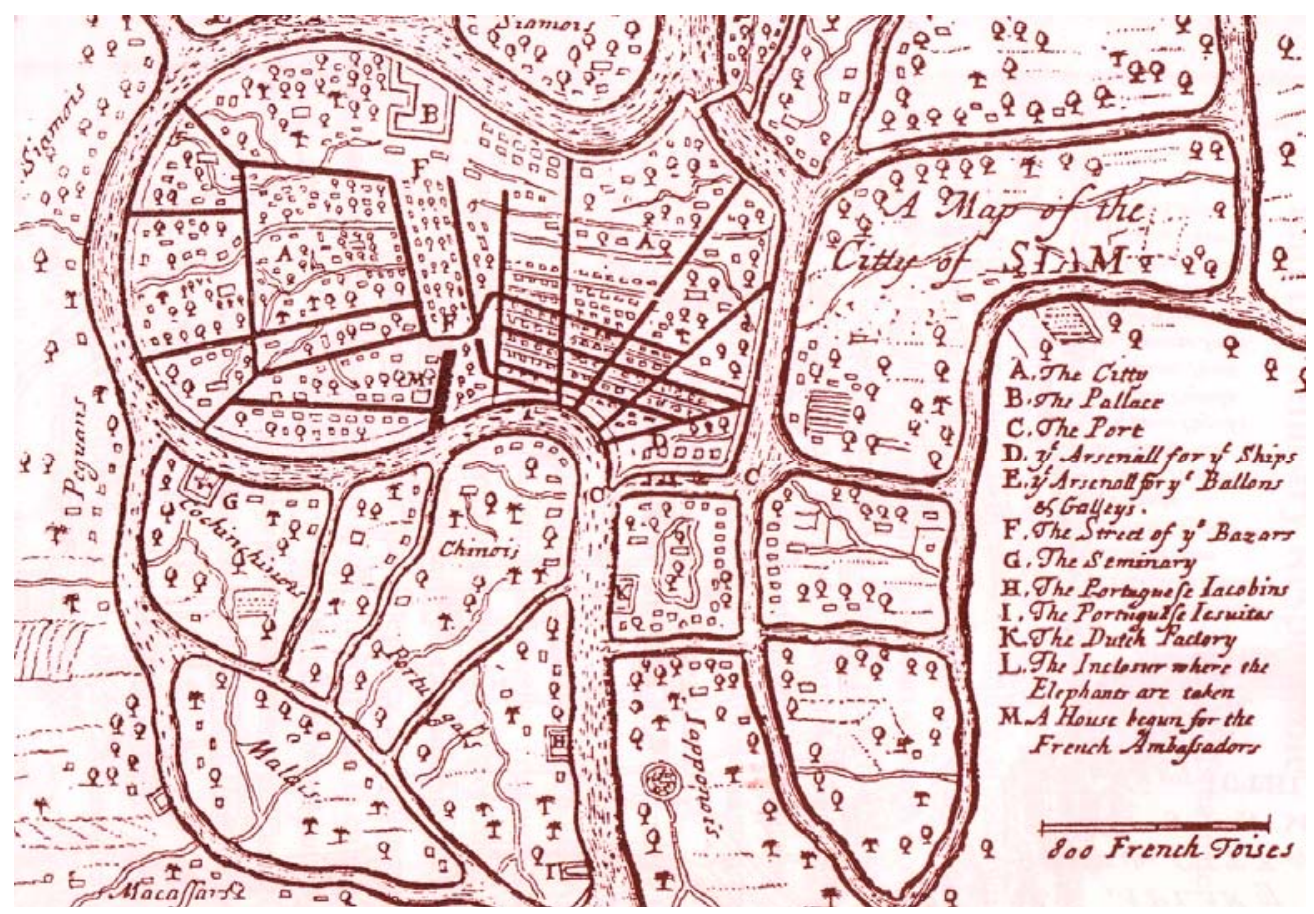

Simon de la Loubère's Ayutthaya City Map

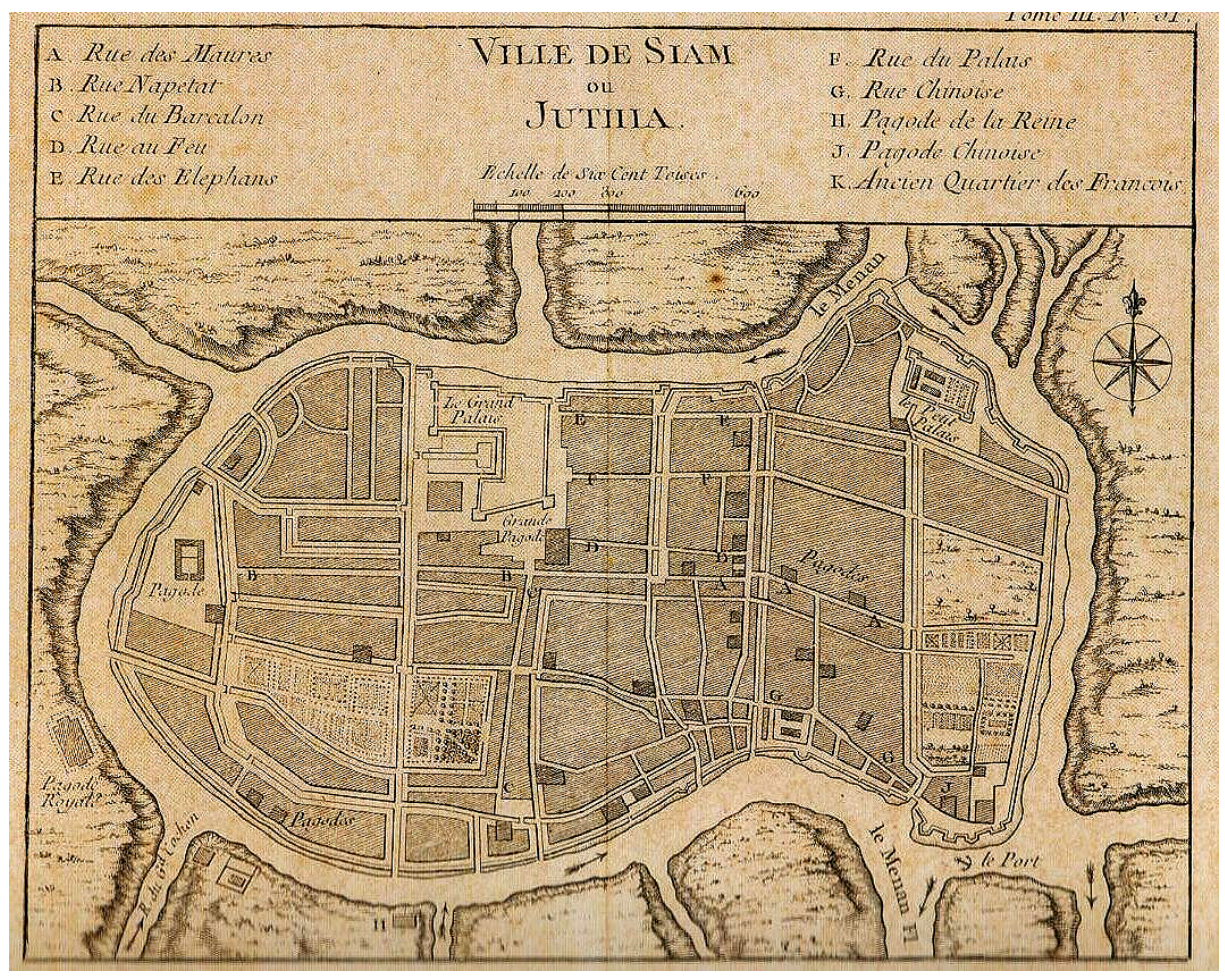

The French Ayutthaya City Map in the Seventeenth Century 


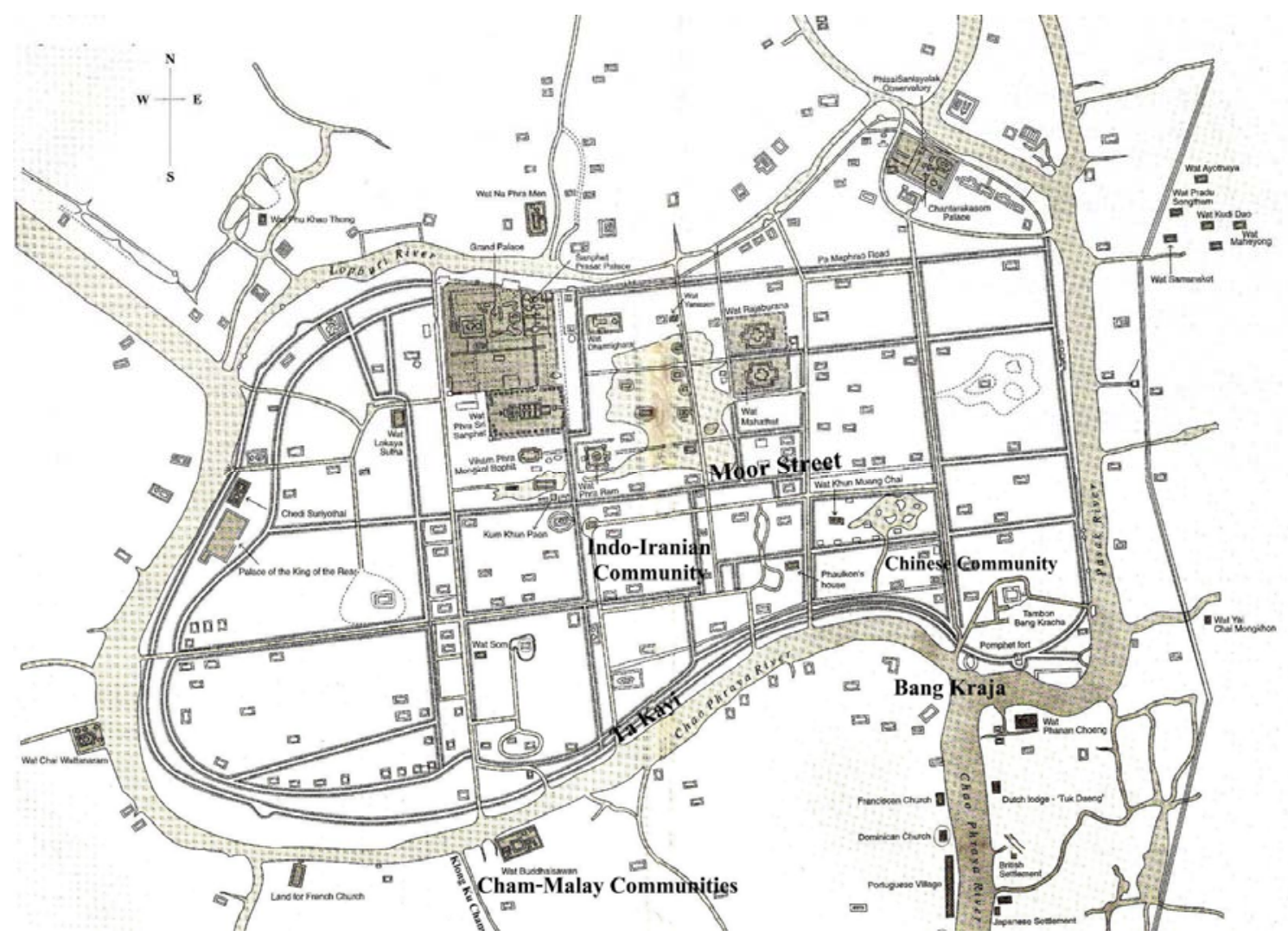

Muslim Communities in the City of Ayutthaya

The Cham, or Khaek Cham, they originated in the south of present-day Vietnam in the area of the the Mekhong River delta. A group of Cham migrated to settle in Ayutthaya during the early Ayutthaya period, with communities at the mouth of $\mathrm{Ku}$ Cham Canal, or in old documents Pata $\mathrm{Ku}$ Cham meaning 'the village of the Cham ${ }^{13}$ located in the south

${ }^{13}$ Pata, a Cambodian word, means 'camp' or 'village'. Thus, Pata Ku Cham is 'village of Cham people'. It is recorded in Phra Racha Phongsawadan Krung Kao Chabab Luang Prasoet ('Royal Chronicle of Ayutthaya Version of Luang Prasoet') in 1409 that King Ram Racha (1395-1409) ordered the arrest of Okya Mahasena, the Minister of State, for his of the city of Ayutthaya near Wat Buddhai Sawan. This area was considered one of

opposition, but he was able to escape from the king's hand by crossing the river to Pata $\mathrm{Ku}$ Cham. Later, he supported King

Nakarintratiraj, a cousin of King Ram Racha and the ruler of the city of Supanburi, in a fight to overthrow his cousin. After King Nakarintratiraj assumed the throne, he banished his cousin to live in Pata Ku Cham. Muslim communities have existed in the area of Pata $\mathrm{Ku}$ Cham up to the present time. See also Phra Racha Phongsawadan Krung Sri Ayutthaya Chabab Luang Prasoet lae Chabab Kromphra Paramanuchit 'The Luang Prasoet Version and the Prince Paramanuchit Version of Royal Ayutthaya Chronicles' (1961: 4); Kongchana, (1981: 71). 
the four large markets around the capital city. ${ }^{14}$ The Cham people came into Siam periodically, partly to trade and partly due to political problems caused by the Vietnamese invasion of the Kingdom of Champa at the end of the sixteenth century, so that a number of Cham people had to flee to Java, Malaya, Cambodia, and Siam (Hall, 1980: 68). Additionally, the Cham that migrated to Cambodia were taken prisoner when the Siamese army invaded Cambodia. ${ }^{15}$ When more Cham refugees arrived, the communities expanded to settle along the two sides of the $\mathrm{Ku}$ Cham Canal. The Cham communities settled near the Muslims from Malaya and Makassar as they belonged to the same Muslim sect.

Foreign evidence from the reign of King Narai suggests that this group of Muslims was the largest. La Loubère said that there were three or four thousand Moors in

\footnotetext{
${ }^{14}$ The four famous floating markets around the city of Ayutthaya were the Nam Won Ban Kraja Market in front of Phranang Chueng Temple, the Pak Khlong Ku Cham Market near the Cham community, the Ku Mai Rong Market, and the Pak Khlong Wat Derm (Ayutthaya Temple) Market near the Chinese temple. See also Khamhaikan Khunluang Wat Pradusongtham Ekasan jak Horluang (1985: 3).

${ }^{15}$ The Cham Muslims, originating in the Kingdom of Champa in the south of what is now Vietnam, were invaded by the Vietnamese during the fourteenth and fifteenth centuries. They were forced to migrate from their homeland to neighboring countries. Some of them migrated to Cambodia and set up communities in Kampong Thom and Kampong Cham near the Mekong River. They were forcibly moved to Ayutthaya when the Siamese troops invaded the kingdom of Cambodia in the fifteenth century. See also Kongchana (1981: 71), Whitaker (1973: 73), and Scupin (1980: 68).
}

Siam, as many Portuguese born in India, as many Chinese, and perhaps as many Malays, besides those who come from other nations (La Loubère, 1969: 112). Gervaise stated that the Malays in Siam outnumbered the other Muslim groups (Gervaise, 1989: 58) and that this group of Muslims worked as merchants, shipping crews, craftspeople, farmers, and civil servants. The merchants and shipping crews were interconnected, with many Muslim merchants also being ship masters, as the Malays were also expert in shipping, like the Cham.

\section{Khamhaikarn Khunluang Wat Pradu} Songtham states that the Khaek Java and the Malays came by ship to trade with Siam annually. The area of the mouth of $\mathrm{Ku}$ Cham Canal was the location for the Muslim merchants from Java and Malaya to sell beetlenuts, rattan and other baskets, and goods from the south. Their customers consisted of Chinese, Khaek, French, English, Dutch, and Portuguese merchants. Other groups of Muslims engaged in the crafts were the Chams, who wove materials and mats, and the Malays, who made cabin ropes from coconut husks and welded boat anchors to sell to foreign ship captains (Pongsripean, 1985: 7). Another group of Muslims must have been farmers, ${ }^{16}$ because there was community production of local sustainable-livelihood products, which were rice, agricultural produce, and animal products.

Another profession of this group of Muslims was civil service, as evidenced in

\footnotetext{
${ }^{16}$ Kongchana explained that in the Ayutthaya period the Cham communities situated near the $\mathrm{Ku}$ Cham Canal formed a farming society. They grew floating rice on the bank of the canal near their villages. See Kongchana (1981: 77).
} 
the Phra Aiyakan Tamnaeng Na Tahan Hua Muang 'Law of the Military and Provincial Hierarchies', which mentioned The Krom Asa Cham 'Cham Volunteer Corps' as a division of the Ministry of Defence with Phraya Raj Wangsan as chao krom 'division chief' in charge of the Cham volunteers, who were Muslims of Cham and Malay descent (Kotmai Tra Sam Duang Lem 1, 1962: 308). Some of the Muslims in this community were civil servants in the capital city. Khamhaikarn Khunluang Wat Pradu Songtham mentioned that, in the area at the mouth of the $\mathrm{Ku}$ Cham Canal, there was an important thanam 'river ferry', was called Phraya Raj Wangsan Thanam which was used to cross between the south side and inside the capital (Pongsripean, 1985: 2). The ferry was located near the house of Phraya Raj Wangsan, the division chief of the Krom Asa Cham, who was in charge of the Cham communities in Ayutthaya. Part of the Cham and Malay Muslims who were civil servants in the Krom Asa Cham must have used this ferry to travel between inside the city wall and their communities at $\mathrm{Ku}$ Cham Canal.

Khaek Thet Groups, Muslims from Pattani, and Groups of Muslims with Small Enterprises settled in communities next to the city wall on the outside, near canals or rivers on the south of the city island. They were Khaek Tani (Pattani Muslims) and Khaek Thet. The Khaek Thet may have been the Arabian or Indian Muslims who resided in the Tha Kayi area which was the old Khaek area of Ayutthaya. They built houses on the capital city side in the east and south (Diwongsa, 1987: 19). This group of Muslims consisted of both small enterprise merchants selling in the city markets and merchants selling from ships anchored around Ban Nam Won Bang Kraja Market.

The Ban Nam Won Bang Kraja Market area was where the two rivers joined, namely the Chao Phraya River and the Pasak River, on the southeast of the city island of Ayutthaya. It was the route for local merchants to ship merchandise from the north to sell, and foreign merchants would bring their ships to offload and buy local goods. The Muslims in this area were mainly merchants and craftspeople, building their homes along the Chao Phraya River. The merchants would sell to foreign ships and at the same time buy their goods to sell in the city markets. ${ }^{17}$ The craftspeople who were Khaek Thet and Khaek Malay made cabin ropes from coconut husks and welded boat anchors to sell to foreign ship captains. Others were the Khaek Tani who lived near Wat Lodchong and wove silk and cotton materials, both plain and patterned, which they sold (Pongsripean, 1985: 7).

Indo-Iranian Muslims consisted of Muslims of Iranian, Arabian, Turkish, and Indian descent. They were Muslims of the Iranian and Indian race, including those of mixed blood of the Iranians and Indians. However, it was difficult to determine the real ethnicity of this group because Iran was a place of many races that were already mixed to a certain level ( Chardin, 1988: 126), ${ }^{18}$ as was also true for with the

\footnotetext{
${ }^{17}$ There were the Khaek Thet (Muslims from countries of Siam) shops where jewellery and brasses were sold at the Shikun Market in the city wall (Pongsripean, 1985: 15).

${ }^{18}$ The major groups of Iranians are the Persian, the Kurdish, the Gilani, the Mazanderani, the Lori, and the Baluchi, and the majority of nonIranian races are the Semitic, or Arabs, and the Turkish. See also John W. Limber, 1987: 21.
} 
Muslims in India, who were a mix of locals and Muslims from Arabia, Turkey, and Iran (Raychaudhuri and Majumdar, 1987: 451-452, 469).

Western documents generally called this group of Muslims generally as Moors which was the term the Portuguese and Spanish used for Muslims who came from North and East Africa, the Middle East, Central Asia, and India. It was a generalized term that did not distinguish races, regions, or religious sects. When other Westerners came to Asia later, they also used the term Moors, as recorded in the account of la Loubère, as follows:

The Moors alone which ought to be reckon'd only for one, do make more than ten, as well for that they came to Siam from different Nations, as for their being of various conditions, as Merchants, Soldiers, and Labourers. (I call Moors after the Spanish manner, not the Negroes, but those Mahometans of Arabian Extraction, which our Ancestors have called Saracens, and whose race is spread almost through) (La Loubère, 1969: 11).

The word Moors in Western documents therefore included the Muslims from western Asia and sometimes also Muslims from India. As explained by the Chevalier de Chaumont, the first French envoy sent by King Louis XIV to King Narai's court in 1685, under the name of Moor were comprehended Turks, Persians, Moguls,
Golcondans, and those of Bengal (Smithies, 1997: 84).

The Siamese during the Ayutthaya period called the Indo-Iranian Muslims by various names, for instance, Khaek Chao Sen, Khaek Maghon, Khaek Yai and Khaek Thet. The words Khaek Chao Sen were used by the Siamese to denote Muslims of the Shiite sect, Chao Sen being the name of Imam Hussein, one of the most important imams in Shiite Islam, the sect of Islam with the second largest number of followers, next to the Sunni sect. The Siamese called the Indo-Iranian Muslims Khaek Chao Sen because, during the Ayutthaya period, they were Muslims of the Shiite sect. Westerners recorded that the Moors in Siam were a different sect of Muslims from the Malays (Smithies, 1997: 84, and Gervaise, 1989: 175) as the Malays were Sunni Muslims of the Shafi'is sect, while the Moors in Siam were mostly Shiite Muslims of the IthnaAsharis sect. ${ }^{19}$

Some experts said the term Khaek Maghon came from the word Mogul or Mughal (Kanjanakphan, 1974: 49) because the Siamese people thought that this group of Muslims were Khaek Mughal (although the Mughal Indians were actually Sunni Muslims) or because they were using the Western terms of Moors, Mughals or Mouros. Maghon may also have come from the word Mahol, which the Iranians used to refer to Indian Muslims, as evidenced in The Ship of Suleiman, a journal of the Iranian envoy from the

\footnotetext{
${ }^{19}$ Ithna-Asharis is the name of a branch of Shiite Islam that believes in twelve Imams (ithna 'ashar meaning 'twelve' in Arabic) beginning with Ali, the cousin and son-in-law of the Prophet Muhammad, and ending with Muhhammad al Mahdi, the twelfth Imam.
} 
Safavid Shah Sulaiman of Iran to King Narai's court in 1687 . It was recorded that 'the Mahols' were Shiite Muslims from India (Rabi, 1972: 95). Thus the term Khaek Maghon should have meant the Indo-Iranian Shiite Muslims. This term appeared in Karp Hor Khlong wa duay Ngan Nakhattaruek by King Rama II, which mentioned the Muharram Ceremony, a procession ceremony in devotion to the martyrdom of Imam Hussein of the Khaek Chao Sen or Khaek Maghon in Siam (Prachum Karp Hei Ruea Samai Ayutthaya, 1961: 28). Nang Sue Sadaeng Kijjanuketh of Chao Phraya Thipakaravongse (Kham Bunnag), the Siamese Minister of Trade and Commerce, which was written during the reign of King Rama IV, called the Khaek Chao Sen or Shiite Muslims Khaek Mahol or Khaek Maghon (Chao Praya Thipakaravongse, 1979: 131).

In all of the various foreigners' descriptions, the residences of this group of Muslims were said to be inside the city wall near the Chinese district, with houses and shops along the large brick road which lead to the Grand Palace (Gervaise, 1989: 39; Smithies, 1993: 165; and Kaempfer, 1987: 4). The Indo-Iranian Muslims had their communities in the commercial district of Ayuthaya, from the Chinese gate to the gate south of Tha Kayi. ${ }^{20}$ Khamhaikarn Khunluang Wat Pradu Songtham described the area of residence

\footnotetext{
${ }^{20}$ Tamra Baeb Thamniam Nai Rajchasamnak Khrang Krungkao 'The Book of Court Custom in the Ayutthaya Period' mentions that two Muslim officials, Khun Koja Ishak and Khun Raja Setdhi, had the responsibilities of overseeing and protecting the Muslim district from Pratu Chin 'Chinese Gate' to Pratu Tai Tha Kayi 'Gate South of Tha Kayi'. See also Fine Arts Department (1961: 519).
}

of these Muslims as almost in the center of the capital city and because the Siamese called these Muslims Khaek Thet, Khaek Yai or Khaek Chao Sen, the landmarks in the area of these communities bore the name, for instance, Ban Khaek Yai Chao Sen, Pratu Thet Canal and Thanon Ban Khaek Yai. ${ }^{21}$ In this area, there were houses and shops along the roads that were called bazaars which were depicted in Westerners paintings as a row of shops parallel to the roads. The Indo-Iranian Muslims also built religious places in their communities, ${ }^{22}$ as evidenced by French accounts from the reign of King Narai, which mentioned that the Moors performed their religious rites in this area (La Loubère , 1969: 112; Tachard, 1985: 214; and Smithies, 1997: 212).

The main factor that made the Court grant permission for this group of Muslims to settle inside the city, same as the Chinese had, was the importance of the community to local and international trade. The Muslims inside the city wall were merchants who bought luxurious goods to sell, such as Persian carpets, rose water, brocades, jewelry and gold ornaments. ${ }^{23}$

\footnotetext{
${ }^{21}$ It was probably called Shikun Street in Thai nowadays, from Sheikh Street, which means the Street of Master Khaek.

${ }^{22}$ Phraya Boran Rajchatanin, the Lord Lieutenant of Ayutthaya's district in King Rama V's reign, called Tung Khaek ('Muslim Range'), stood in the area of the modern Phranakorn Si Ayutthaya Rajabhat Institute. There are some ruins of the building there, including an Indo-Iranian style arc bridge and a pedestal of the religious building. See also Fine Arts Department (1971: 72-73).

${ }^{23}$ Dutch trade records stated that clothes and golden treasures from Persia were highly valued in the Ayutthaya market. See also Suthtakul (1971: 72-73). The records of French merchants mentioned that some of the
} 
These goods were expensive and bought by the rich, courtiers, the royal family, and the King, all of whom resided within the city wall. These merchants must have been selling to rich and powerful people in the capital city from the beginning, so they received special permission to set up their communities in the important areas of Ayutthaya. The French missionary Nicolas Gervaise, who came to Ayutthaya in 1683 during the reign of King Narai, pointed out that the Moorish merchants played as much a role as the Chinese merchants in the commerce of Siam (Gervaise, 1989: $63)$.

Indo-Iranian Muslims also worked in the government, both the military and civil service. The ones in military service were in the Kong Asa Tang Chat 'Foreign Volunteer Corps' and the Royal Guards, appointed by the King to work in special forces who may have been volunteers or foreign volunteers specifically employed for this purpose. ${ }^{24}$ Rabi mentioned that King Narai employed 200 Iranians from India as his Royal Guards (1972: 100), while Guy Tachard, who came to

presents which were given to Constantine Phulkon, King Narai's Greek counselor, included Persian wine, rose water, and Persian fruits. See also Prachum Phongsawadan Phak Thi Si (1968: 270).

${ }^{24}$ Somdej Kromphraya Damrong

Rachanuphab (Prince Damrong Rachanuphab), the Minister of the Interior in King Rama V's reign, explained that the Kong Asa Tang Chat were originated by foreigners who had military skills and volunteered for in the Siamese army. Later, they were collected into the Kong Asa 'Volunteer Corps', which were separated by their nations, for example, Kong Asa Nippon 'Japanese Volunteer Corp', and Krom Asa Cham 'Cham Volunteer Corp Division', and were sent into the battle. See also Rajanuphab, (1991: 242).
Ayutthaya for the first time in 1685 during the reign of King Narai, described the welcome ceremony for the French diplomatic corps of the Chevalier de Cheaumont, which included a company of Moorish soldiers on horseback carrying spears, on duty on the second level of the Royal Palace. On the fourth level of the palace, in the two side halls, there were around 500 Persian Royal Guards (Tachard, 1985: 166). The Indo-Iranian Muslim Volunteer Corps must have resided inside the city wall in the same manner as other Muslims of the same race, as they had to work in close contact with the King and also had to perform religious rites with their communities.

As for those in civil service, most were attached to the Krom Tha Khwa, the Siamese Western Maritime Trade Affair, and also resided inside the city wall. The notes on the history of Chao Phraya Bovorn Rajanayok, named Sheik Ahmad, an Iranian merchant who came to trade, joined the civil service during Ayutthaya period, and was later appointed as an official of the Krom Tha Khwa, explained that Sheik Ahmad was granted land in the area of Tai $\mathrm{Ku}$ to build houses, religious structures, and communities (Tipakonlawongse, 1970: 2- 3; Komarakul Montri, 1969: 11-12). In later times, the descendants of Sheik Ahmad in later times also worked in the Krom Tha Khwa and other civil service units.

The establishment of communities of Muslims separated into three groups resulted from the fact that the number of Muslims was great enough to allow themselves to set up large communities in Ayutthaya. But there were other smaller groups of Muslims that were also spread around Ayutthaya, for example the Kling, the Chulia, the Gujarati, and the Bengali 
(Andaya, 1999: 135). The Chulia played an important role in the trading of tin and elephants from Siam in the seventeenth century. ${ }^{25}$ These Muslims generally came from India and were Sunni Muslims of the Hanaf' is and Shaf' is groups. This group of people's role was the import and export of goods to and from Siam, so they must have settled near the river where the merchant ships were moored, in the area of Ban Nam Won Bang Kraja, where there were communities of Muslims from India. Some also had shops inside the city wall.

Apart from Ayutthaya, the Muslims also resided in important towns on the trading route, which were mostly seaside towns or large cities. Western documents in the seventeenth century stated that the Muslims came to settle and trade in the entrepôts of Tavoy, Mergui, and Tanasserim. The commercial report of George White, an Englishman who came during the reign of King Narai, said of the settlement of the Muslims in Mergui and Tanasserim that there were as many Muslims as the original local people, due to the encouragement of Okphra Sri Navarat, an Iranian official in the Siamese Court (Prachum Phongsawadan Lem Ha, 1964: 505). Rabi said that the houses of the Iranian Muslim officials in the town of Mergui were well built. Concerning the Muslim communities in Tanasserim he explained that the people of this town consisted of the Siamese and Indian Muslims of both Shaf'is and Hanaf'is

\footnotetext{
${ }^{25}$ Chulia is a Tamil Muslim originating from intermarriage between Muslims from western Asia and local southern Indian Tamil women. The Chulia merchants traded by sea from India to the southern part of Siam, the Malay peninsula, and the Indonesian archipelago. See also Andaya (1999: 133) and Gupta (1994: 361).
}

groups (Rabi, 1972: 46-47). The Muslims also had communities in many other cities such as Lopburi, Pipplee (Petchburi), and Suhol, which Rabi mentioned as a town on the route from Petchburi to Ayutthaya, plentiful with fruit orchards, whose Governor was a Turkish Muslim of the Shiite sect (1972: 50-51).

The History of the Tonson Mosque told the history of an important mosque in the community centre in the late Ayutthaya period. There was a settlement of Muslim traders around the Bangkok Yai canal on the Thonburi side. ${ }^{26}$ The History mentioned that, at the time of the fall of Ayutthaya, there was a wooden board engraved in the Arabic language, partly burnt by fire, that floated down river and was picked up by the Muslims in Bangkok Yai Canal and preserved in the Tonson Mosque yo the present day (Chitmoead, 1987: 125, and History of Masjid Tonson, 1975: 13). The Muslims in the Tonson Mosque area must have been settled there since the Ayutthaya period, because a note on the memoir of Muslim officials in the Krom Tha Khwa during the early Rattanakosin period stated that, when they ran away from the destruction of Ayutthaya by the Burmese troops in 1767, they came to stay in the Kudi Yai area ${ }^{27}$,

\footnotetext{
${ }^{26}$ This Muslim group believes that their ancestors had originally situated the community on the bank of the Bangkok Yai Canal until the reign of King Songtham in the Ayutthaya period (1610-1628). See also Chitmoead (1987: 125).

${ }^{27}$ The other name of Ton Son Mosque is Kadi Yai or Kudi Yai, probably from Kadi Bangkok Yai, because it is situated near the Bangkok Yai Canal in Thonburi province. The word kadi is the common name of a Shiite prayer house in Siam. It might come from the name Gadir Khumm, a locale on the route from Mecca to Medina in Arabia. The Shiites
} 
the area of the Tonson Mosque, with the old communities of Muslims near the Bangkok Yai Canal, which confirms that there were Muslims living in that area from the Ayutthaya period. It can be noted that Muslim communities were located in towns that were strategic for trade from entrepôts to the west, namely Tavoy, Mergui, and Tanasserim, across the continent following the Tanasserim River, to the towns of Petchburi, Bangkok, and Ayutthaya. This formed an important trade route from the Bay of Bengal to the Gulf of Siam.

Lopburi was another town that had Muslim communities. They had been set up when Lopburi was another royal court town during the reign of King Narai. The Ship of Sulaiman mentioned that, while the Iranian diplomatic party were staying in Lopburi, they joined in the taziyat ceremony, an important ceremony of the Shiite Muslims, performed to commemorate the martyrdom of Imam Hussein, the grandson of the Prophet Mohammed. Moreover, they heard the Asan which meant that there were daily prayers of the Muslims in Lopburi (Rabi, 1972: 78), confirming that there were Muslim communities there, as there were mosques to perform religious rites.

believe this locale is the holy place where the Prophet appointed Imam Ali, the leader of the Shiite Muslims, to be his rightful successor. Generally, the Shiites call their prayer houses Imambara, 'house of imam'. In another opinion, kadi is probably from the Malay word katay, meaning an altar or a holy place, which is nearly the meaning of imambara. See also Kulsirisawad, (2002: 14), Chitmoead (1987: 119), Tabatabi (1985: 40), Haim (1996: 46), and Narisaranuvadtivongs (1963: 103-104).
The Muslims in Ayutthaya were divided into distinct groups, especially groups 1 and 2, which were the groups outside the city wall, and group 3, who were inside the city wall. This third group were mainly the Indo-Iranian Muslims of the Shiite sect, which was different from groups 1 and 2, who were mainly of the Shaf'is group of the Sunni sect. The differences in religion, race, society, and culture caused these Muslims to separate into different communities. The Cham-Malay Muslims and the Indo- Iranian Muslims each played an important role in the royal court of Siam. The Cham-Malay Muslims were vital in the Asa Cham, or Cham Volunteer Corps, which was a military unit, while the Indo-Iranian Muslims played a part in the economy and, later on, this group expanded their role into politics and government, too.

It can be said that among the various religious groups, the Muslims played the significant number of roles in the civil service in Siam. These people played a part in administrative positions in both military and civil services. The Muslims used their expertise in various fields to play an active part in the Royal Court. Apart from units that specified Muslims in the direct chain of command, such as the Krom Kanti 'the Eunuchs Department', the Krom Asa Cham and the Krom Tha Khwa, the Muslims served as personnel in many other units, such as the Royal Guards in charge of the Palace Surrounds, the Royal Pages, Royal Attire, Royal Cavalry, Royal Elephant Keeper, and Royal Artillery. They were also Royal Physicians, Poets, Architects, and even Advisors to the King in Religious Affairs such as Toh Rid, Toh Thong and Toh 
Nok, ${ }^{28}$ who advised King Taksin about meditation (Phra Racha Pongsawadan Krung Thonburi,1935: 179). ${ }^{29}$

The Muslims have given much assistance to the country. Many helped to protect Ayutthaya from the Burmese troops and were killed in the fall of Ayutthaya. These people were the main power in setting up Thonburi and Rattanakosin. The Malay Muslims were the force that produced rice to feed the people of Rattanakosin from the time of King Rama I. Cham Muslims have fought and lost their lives in many wars to protect the country. Indian Muslims played a role in the development of trade, especially teakwood and cloth, so that teak became a prime export and the Siamese had good cloth to wear. Not only the officials but also the small communities of Muslims were also involved in rolling the wheel of history. The stories of these people are a lesson for later generations to study and learn of the harmony of the people of a different race and religion who have helped to keep peace in Thai society up to the present time.

\section{References}

Andaya, Leonard Y. 1999. 'Ayutthaya and the Persian and India Muslim Connection' in From Japan to Arabia: Ayutthaya Maritime Relations with Asia. Bangkok: The Foundation for the Promotion of Social Sciences and Humanities Textbooks Project.

\footnotetext{
${ }^{28}$ Toh comes from the Malay word da toh, meaning a Muslim expert or the senior person in the Muslim community.

${ }^{29}$ I assume that this refers to Sufi meditation (Islamic mysticism).
}

Barbosa, Duarte. 1967. The Book of Duarte Barbosa. Vol. 2. Millwood and New York: Kraus Reprint.

Bunnag, Kham. 1979. Nang Sue Sadang Kijjanuketh. Bangkok: Kurusabha.

Cadi, John F. 1964. Southeast Asia: Its Historical Development. New York: McGraw Hill.

Chardin, John. 1988. Travels in Persia 1673-1677. New York: Dover Publication.

Chaudhuri, K.N. 1989. Trade and Civilisation in the Indian Ocean. Cambridge: Cambridge University Press.

Chaudhuri, K.N. 1990. Asia Before Europe: Economy and Civilization of the Indian Ocean from the Rise of Islam to 1750. Cambridge: Cambridge University Press.

Chitmoead, Saowanee. 1987. Tribal Groups: Thai Muslim. Bangkok: Rujiraamporn Fund.

Chaumont, Chevalier de, and Abbé de Choisy. 1997. Aspects of the Embassy to Siam 1685. Trans. by Michael Smithies. Chaingmai: Silkworm Books.

Choisy, Abbé de. 1993. Journal of a Voyage to Siam 1685-1686. Trans. by Michael Smithies. Kuala Lumpur: Oxford University Press.

Chularatana, Julispong. 1999. Aqa Muhammad Astarabadi: The Iranian Vizier in the King Narai Court. Arts \& Culture, 20: 107. 
Cortesoa, Armando, tr. and ed. 1990. The Suma Oriental of Tomé Pires and the Book of Francisco Rodriques Vol. 1. New Delhi: Asian Educational Services.

Damrong Rachanuphab, Prince. 1991. Phra Ratchaphongsawadan Krung Sri Ayutthaya Chabab Phra Ratchahatthalekha. Bangkok: Chunum Sahakorn.

Datta, Kalikinkar, H. C. Raychaudhuri, and R. C. Majumdar. 1987. An Advanced History of India. Madras: Macmillan.

Denny F.M. 'Umma' in The Encyclopaedia of Islam Online. Available on-line at http://www.encislam.brill.nl/start2.a sp.

Diwongsa, Komkam. 1987. The Role of Ayutthaya's Market Places in Internal and External Trade (16301767). MA Thesis, Department of History, Faculty of Arts, Chulalongkorn University.

Dunn, Rose E. 1989. The Adventures of Muhammad Rabi Battuta. Berkeley: University of California Press.

Ezzati, Abul-Fazl. 1944. The Spread of Islam. Ghom: The Ahl Ul Bayt World Assembly.

Fine Arts Department. 1961. Latthi Dhamniam Tangtang. Vol. 2. Bangkok: Khurusabha.

Fine Arts Department. 1971. Athibai Panti Phranakorn Sri Ayutthaya Kab Kham Winichai Kong Phraya Boran
Ratchatanin Rueng Silpa Lae Bhumisathan Krung Sri Ayutthaya Lae Jangwat Phichit. Bangkok: Sammitre.

Gervaise, Nicolas. 1989. The Natural and Political History of the Kingdom of Siam. Trans. by John Villiers. Bangkok: White Lotus.

Gupta, Ashin Das. 1994. Merchants of Maritime India 1500-1800. Brookfield: Ashgate.

Haim, S. 1996. Farhang Mo'aser's Shorter Persian-English Dictionary. Tehran: Farhang Mo'aser.

Hall, D. G. E. 1968. A History of SouthEast Asia. London: Macmillan.

History of Masjid Tonson. 1975. Bangkok: Eid-al-Adha.

Kaempfer, Engelbert. 1987. A Description of the Kingdom of Siam 1690. Bangkok: White Orchid Press.

Kanchanakphan. 1974. Phumisart Wat Poh. $2^{\text {nd }}$ ed. Bangkok: Burinth Publishers.

Komarakul Montri, Phraya. 1969. Sheik Ahmad. Bangkok: Borpith Publishers.

Kongchana, Plubplung. 1999. Historical Development of Cham Communities in Ayutthaya. Warasan Prawatisat, $67-80$.

Kotmai Tra Sam Duang. 1962. Vol. 1. Bangkok: Khurusabha. 
Kulsirisawad, Direk. 2002. The Muslim Relations in Thai History and Literature. Bangkok: Matichon.

La Lubère, Simon de. 1969. The Kingdom of Siam (Translated from Description du Rouaume de Siam). Singapore: Oxford University Press.

Lieberman, Victor. 1993. 'Local Integration and Eurasian Analogies: Structuring Southeast Asian History, c.1350-1830' Modern Asian Studies, 27.3: 475-592.

Limbert, John W. 1987. Iran at War with History. Boulder: Westview Press.

Mannan, M. Abdul. 1996. Islamic Economy. Trans. by Manjong Bin Kasan. Bangkok: Natcha Publishing.

Mathee, Rudolph P. 1999. The Politics of Trade in Safavid Iran. Cambridge: Cambridge University Press.

Meillink-Roelofsz, M.A.P. 1962. Asian Trade and European Influence in the Indonesian Archipelago between 1500 and about 1630. The Hague: Nijhoff.

Moreland, W.H. 1939. 'The Ships of the Arabian Sea around A.D. 1550' Journal of the Royal Asiatic Society, 63-74, 173-92.

Moreland, W.H. 1920. 'The Shahbander in the Eastern Seas' Journal of the Royal Asiatic Society, 517.

Narisaranuvadtivongs, Prince. 1963. Banthuek Rueng Khwam Rue Tangtang. Bangkok: Thai Wattanapanich.
Pinto, Fernão Mendes. 1904. Subsidios para a sua Biografia. Trans. by Christovao Aires. Lisbon: Academia das Ciencias.

Pinto, Fernão Mendes. 1989. The Travels of Mendes Pinto. Trans. and ed. by Rebecca D. Catz. Chicago: The University of Chicago Press.

Pongsripean, Winai. 1985. Khormun Prawattisart Thai Samai Ayutthaya Jak Ekasarn Thai lae Tangprated. Nakhorn Prathom: Department of History, Faculty of Arts, Silpakorn University.

Pongsripean, Winai, ed. 1991. Khamhaikarn Khunluang Wat Pradusongdham Ekasan Jak Horluang. Bangkok: The Secretariat of the Prime Minister.

Phra Racha Phongsawadan Krung Kao Chabab Luang Prasoet lae Chabab Krommaphra Paramanuchit lae Phongsawadan Noe Chabab Phra Wichienpreecha (Noi). 1961. Bangkok: Khurusabha.

Phra Racha Phongsawadan Krung Thonburi. 1935. Bangkok: Pimthai Books.

Prachum Karp Hei Ruea Samai Ayutthaya. 1961. Bangkok: Khurusabha.

Prachum Phongsawadan. 1964. Vol. 5. Bangkok: Kaonar.

Prachum Phongsawadan Phak Thi 41 Jotmaihet Pohka Farangset. 1968. Bangkok: Khurusabha. 
Rabi, Muhammad. 1972. The Ship of Sulaiman. Trans. by John O' Kane. London: Routledge \& Keagan Paul.

Reid, Anthony. 1988. Southeast Asia in the Age of Commerce 1450-1680. Vol. 2. Chiangmai: Silkworm Books.

Reid, Anthony. 1999. Economic and Social Change, c. 1440-1800. In The Cambridge History of Southeast Asia Vol. 1, Part 2. Singapore: Craft Print.

Risso, Patricia. 1995. Merchants and Faith: Muslim Commerce and Culture in the Indian Ocean. Boulder: Westview Press.

Roberts, R. 1971. The Social Laws of the Qoran. London: Curzon Press.

Saranukrom Thai Chabub Racha Bandithayasadhan. 1969. Bankok: The Royal Institute of Thailand.

Sardesi, D.R. 1994. Southeast Asia Past \& Present, $3^{\text {rd }}$ ed. San Francisco: Westview Press.

Scupin, Raymond. 1980. Islam in Thailand before the Bangkok Period. The Journal of Siam Society 69:68.

Tabatati, Allamah Sayyid Muhammad. 1985. Shi'a. Trans. by Sayyid Husayn Nasr. Qum: Ansariyan.

Tachard, Guy. 1999. A Relation of the Voyage to Siam. Bangkok: White Lotus.

Teeuw, A., and David K. Wyatt. 1970. The Story of Pattani. Vol. 2. The Hague: Nijhoff.
The Dutch Papers in Ayutthaya Period. 1970. Trans. by Nantha Suthnakul. Bangkok: Khurusabha.

Thipakornrawongsa, Chao Phraya. 1970. Jotmaihet Pathom Wong Sakul Bunnag. Bangkok: Phra Chandra.

Udovitch, Abraham L. 1970. Commercial Techniques in Early Medieval Islam Trade. In D.S. Richards (ed.), Islam and the Trade of Asia. London and Colchester: Spottiswoode, Ballantyne.

Whitaker, Donald P. 1973. Area Handbook for the Khmer Republic (Cambodia). Washington: U.S. Government Printing Office.

Winstedt, Richard. 1961. The Malays. $6^{\text {th }}$ ed. London: Routledge \& Kegan Paul. 